\title{
How to Stop Vote Buying: What did Researchers Say?
}

\author{
Hendra Try Ardianto \\ \{hendratrya@lecturer.undip.ac.id\} \\ Universitas Diponegoro, Indonesia
}

\begin{abstract}
This article presents how researchers who wrote the vote-buying phenomenon gave proposed recommendations or solutions in order to stop it. By considering this phenomenon will damage the political representation system and produce less qualified leaders, it is important to trace this solution map. Relying on secondary data from various literatures, the author tries to trace and map vote-buying out in various places which has been discussed by the academics. The results showed that the causes of the phenomenon can be viewed from the actor's perspective, i.e., candidates, constituents and brokers. Meanwhile, there are at least four solutions found, those are making vote-buying as crime act; socialization and political education on anti-vote buying; the reform of political party institutional which is intended to carry out ideological-based works; and strengthening civil society's bargaining position in electoral politics.
\end{abstract}

Keywords: Vote-Buying, Election, Patron Client, Broker, Political Party

\section{Introduction}

Recent contemporary political discussions begin to re-examine the discourse of liberal democracy. The installation of liberal democracy in several countries has actually created new paradoxes. In the last two decades, several pathological phenomena such as local strongmen [1], bosses [2], shadow state [3][4], and dynasty politics [5][6], have emerged in liberal democratic countries. These phenomena can be easily found in many countries.

The existence of electoral democracy did not automatically present democratically social and political orders. The change of power through the electoral mechanism still presents oligarchic elites who hijack and ultimately dominate the democratic system [7][8]. Such realities give rise a pseudo-democracy, or in some academics terms, illiberal democracy; a political system and governance depended on electoral democracy but citizen did not have enough freedom and could not access candidate who won the election [9][10]. The chosen candidate, in other words, tried to seek their own interest in spite of being responsible to the citizen they represent.

Departing from such conditions, antipathy towards electoral processes grows more abundantly among many people along the increasing cases of this malpractice during the election. Cases such as political bribery [11], vote-buying, vote-trading [12], vote-forgery [13], and other election fraud [14], frequently found in the liberal-democratic countries before, during and after electoral processes. At the same time, the election also produced social high political tension and prolonged political polarization [15]. A bad electoral process, on a certain scale, has even resulted in conflict and violence [16].

In this paper, the author will elaborate vote-buying as one of the malpractices in the election. Political scientist defines vote-buying as "the systematic distribution of cash 
payments and/or goods to voters in the few days leading up to the election with the implicit expectation that recipients will repay with their vote" [17]. There are several reasons why the author raised this issue. First, the dimension of fraud in this case is much more obscure because practically the citizens involved in this malpractice because they receive money/goods. This is quite different from the practice of political bribery, vote trading, vote forgery, which only involve party elites and government bureaucracy. Second, the practice of vote-buying also insults the meaning of citizen participation because "citizens participate only when they perceive that their vote may have an impact on the election results and the policy outcomes that result from the election" [18].

Research on vote buying phenomenon is not new. There is a fair amount of research on vote buying already done. From these studies, there are two methodological tendencies that are quantitative and qualitative methods. Writers who use quantitative typically construct arguments related to the reasons, and the motivations behind vote buying practices. Meanwhile, those who use qualitative methods tend to explore more of the socio-political context behind the vote buying practices.

There are general assumptions that vote-buying phenomenon were only happened in developing countries such as African [19][20], Latin American [21][22][23], South Asian [24][25], and Southeast Asian countries [26][27]. But, in fact, similar phenomena were also happened in developed countries such as Japan [28], United States [29], and Britain [30]. In other words, such phenomena have spread to all over the world with different features and in accordance with various social and political conditions.

The author will focus to explain on how previous researchers tried to minimize votebuying phenomena by giving solutions or recommendations. Recent discussions on votebuying more directed to the emergence of daily practices of vote-buying behaviour in various context and various countries. They tend to focus their research on detail motivation and what the candidates [31], voters [32], and brokers [33][34] do when they practice vote-buying. For this reason, the author will try to summarize in general the various literature related to solutions in minimizing the vote-buying proposed by the researchers.

In discussing the phenomenon, the author deliberately disregards the context of administrative differences in the scope of observation. It means, both national and village level or both executive and legislative were seen as the same electoral processes. By doing this, two goals were achieved, those are simplifying the observation processes and avoiding scope limitation caused by the choices of analysis at various administrative levels.

This ignore of the administrative context is, of course, a weakness of this paper, where the solution map is insensitive to which level it should be implemented. However, this neglect can actually be an advantage, because regardless of the context, some of these types of solutions can be aggregated as a kind of generic solutions. This is important because so far research on vote buying tends to produce a pessimistic perspective. No researchers really believes that the solution offered can stop the vote buying practice because their analysis is too partial in many levels of administrative/geography.

This paper departed from a research that relies specifically on published journal about vote-buying. The articles used here, nevertheless, were taken from cases generally appeared in developing countries, such as Indonesia, Philippines, Thailand, India, Nigeria, Kenya, and Nicaragua. The choice was not specifically related to the methodological problem but by considering that there are much more vote-buying literatures from developing countries than developed countries. The only article related to vote buying used in this article that comes from developed countries is the case of vote buying in China. 


\section{Result and Discussion}

In this discussion, the author going to display two main landscapes in reviewing votebuying phenomena. At the beginning, the author will overview on causes and consequences of vote-buying practices. It should be done as a starting point to identify how those researchers proposed solutions to stop vote-buying.

\subsection{Causes and Effects}

In reviewing the causes of vote-buying practices, the author will look up from the actor side. Many researches stressed different focal point at the actor level. Therefore, the author will categorize the actor into three categories, i.e, candidate, voter, and broker. By observing those three categories, it is expected the big picture on how the considered solutions was obtained.

From the candidate point of view, some researchers confirm that vote-buying practices emerged because there is a big economic potential from the contested position. Zhao's research (2018) towards 14 villages in Shandong Provinces, China, showed that the emout of money/goods in vote-buying practices actually linear with land's rental price in the village [35].

From the voters point of view, there are various explanations. Some researchers said that vote-buying appears because of poverty [36]. It coud be happened because "low income creates economic pressure to accept money" [32]. In addition, lower education is also viewed as the cause of vote-buying practices. The lower the education of a person, the more vulnerable and tolerant they will be towards vote buying [37]. Poor and uneducated people will lack adequate access to information on the political process [38]. Under such conditions people will easily accept money/goods from the candidate.

There is also cultural explanation which comfirms that vote-buying is patron-client relation. This argument based on the assumption that vote-buying is embedded in the social norms of society, in particular for the norm of mutual help (reciprocity) [39]. People with same identity tends to follow the same social norms. People involved in the same social or religious organizations, for example, will be more tolerant with vote-buying practices because they regard mutual help as a habit among the member of the same community [22].

Patron-client explanation is frequently proposed by the researchers in many researches. In his 2016 survey in Metro Manila, Philippines, Canare, Mendoza, and Lopez [40] found the fact that vote-buying was dominantly used to keep the constituent's loyalty than to change their political preferences. The similar practice was found by Tawakkal \& Garner [41] in Pati Regional Election, Indonesia, although there is only one candidate.

Meanwhile, from the broker point of view, there are several explainations. The existence of this broker cannot be separated from the need for candidates to distribute money/goods for the sake of getting votes. In many places, the brokerage structure adopts a pyramid model which extends from a top-level broker to a pyramid-base broker in charge of providing money/goods directly to constituents [42][43].

There are at least two types of broker. The one is a broker that comes from the candidate's loyalist, and the other is a broker who is intended to seek economic benefits both in the short and long term [33]. Although the economic dimension frequently dominant, there are times when brokers emerge for social reasons, ranging from friendship, membership in organizations [34], and even appear because of promises and prestige to certain candidates [44]. 
The impact of vote-buying can be viewed from two sides, those are before and after the election. While the election process was underway, several problems had arisen when some money and goods were distributed to constituents. One of these problems is the emergence of social tensions between people with different choices. The author's argument rests on Aguilar $\&$ Alis [27] findings which show that citizens tend to find it difficult to reject the practice of vote buying, because refusal to receive money from certain candidate will be interpreted as having political choices as opposed to the money-giving candidate. The situation became more difficult when people who rejects the money will be then labeled as an opponent by the candidate's constituents. This findings was similar with Still \& Dusi [24] research in the South Indian region.

Vote-buying, in particular context, does not merely produce social tension, but also trigger violence. In the Uttar Pradesh region, India, which is familiar with the caste system, rejection of vote buying can be interpreted as a rejection of the position of a more dominant caste. It is not surprising, therefore, the phenomenon of vote buying in this region will always be accompanied by violence in it [45]. Similar phenomena was also occured in Nigeria, Africa, where 1 of 5 people claim to be involved in vote-buying, and 1 of 10 people experienced violence in an election [46].

As for the post-election context, the biggest problem with the consequences of the vote buying practice is the accountability of the elected politicians/leaders. Vote-buying typed politician will tend to be corrupt and ignore welfare redistribution policies. Research by Khemani [47], in Philippines case, shows that regions which have a lot of vote-buying cases tend to produce governments that invest less in the basic service sector, particularly the health sector.

This bad consequences will not only cause the quality of the elected leaders, but also decrease the qualified choice of the citizens [48]. Election routines were increasingly meaningless because the citizens being ignorant to the results of their political preferences. Political parties lose their dignity as a channel for political aspirations and aggregation of citizen. The end of all of this is people no longer believe in political parties. Several findings which show the weakening ties between citizens and political parties support this fact [49][24].

If this kind of phenomenon continues, people's trust in the entire political system will undoubtedly be damaged. Almost bureaucratic institutions lose public trust, as suggested by Still \& Dusi [24] it in their research in South India, because every time an election was held, parties such as police, politicians and gangsters are in the same boat in carrying out the vote buying.

\subsection{How to Stop the Vote Buying?}

Although the vote-buying has been discussed by many researchers, it seems that not many of them have suggested solutions or recommendations to stop this practice. Instead of providing it, they have focused a lot of their attention on the appearances and more detailed activities of the vote buying. Therefore, I am interested in discussing several results which give positive tones related to vote-buying.

First, a recommendation stating that vote-buying can be used as a criminal act issue. This recommendation is perhaps the most resolute but the difficult to implement. In several countries, especially Indonesia, vote-buying issue has actually been considered as a criminal act. Whoever does vote buying will be subject to fines and even imprisonment. Unfortunately, from the many cases reported, these rarely can be proven. There are various reasons why this 
case is difficult to prove, ranging from the short time of proof, the criminal element was not fulfilled, and the difficulty in providing evidence [50][51]. Despite this is highly improbable case, in the 2018 North Padanglawas Regional elections, Ramli Tanjung was sentenced to 1 year in prison on charges of carrying out vote-buying activities [52].

Second, a softer but easier solution is to disseminate the negative effects of vote-buying and political education related to anti-vote buying attitudes. This is not actually new solution. The Nagaland Baptist Church Council (NBCC) in India has been at the forefront of anti-vote buying attitudes in the area. One of the pastors even stated optimistically, "That one day a poor man from this village can contest an election and win" [53]. Not much different from Indonesia, before the election, there are dozens of villages that always declare an anti-vote buying behavior [54][55].

Third, a slightly utopian but reasonable solution is reforming the political parties' institutions. This argument is laid on the fact that the party's ideological closeness to its constituents has fade away. This phenomenon has become an entry point for vote buying practice [48]. Muhtadi's survey [49] shows that people who are tolerant and accept the votebuying practices are those who do not have psychological closeness with certain political parties.

Therefore, it is hoped that the institutional reform of political parties will be able to restore ideology-based party work. In this way, the constituent psychological closeness to the party (Party ID) will grow and ultimately eliminate the practice of vote buying. Considering the strength of figure-based political system [56] and the shift in the type of political party from ideological basis to catch all, although it seems plausible, this solution is a bit utopian [57][58].

The fourth is solution to strengthen bargaining position of civil society in electoral politics. Savirani [56] argued that systematic movement of civil society in electoral politics is able to weaken patronage politics based on vote buying. The best example for it is the efforts of the Indonesian Metal Workers Union Federation (FSPMI) who encourage its cadres to participate in the election. As a result, 2 out of 9 FSPMI cadres who participated in regional election were elected as legislative members through a fair political process. This solution might be expected by Callahan [59] when stating that civic associations are responsible for the emergence of vote-buying practices at election times.

If the fourth method compared to the second, it is possible that the fourth method having more significant impact. This is in line with Callahan's opinion (2005) who cynically regards that campaigning anti-money politics merely produce an anti-political neoliberal system. As Ferguson [60] said that is anti-politics machine will only tend to depoliticize "politics" as technical-administrative work, but ignore the imbalance of power. According to Callahan [61], stopping the vote buying practice is not by cutting clientelist relation and directing citizens to be autonomous and rational, but by improving unequal power relations. Finally, making citizens have a strong political position will automatically remove the anti-political system and the vote-buying practice itself.

The four solutions, which were taken from the previous researchers, can be illustrated simply by using the figure below 


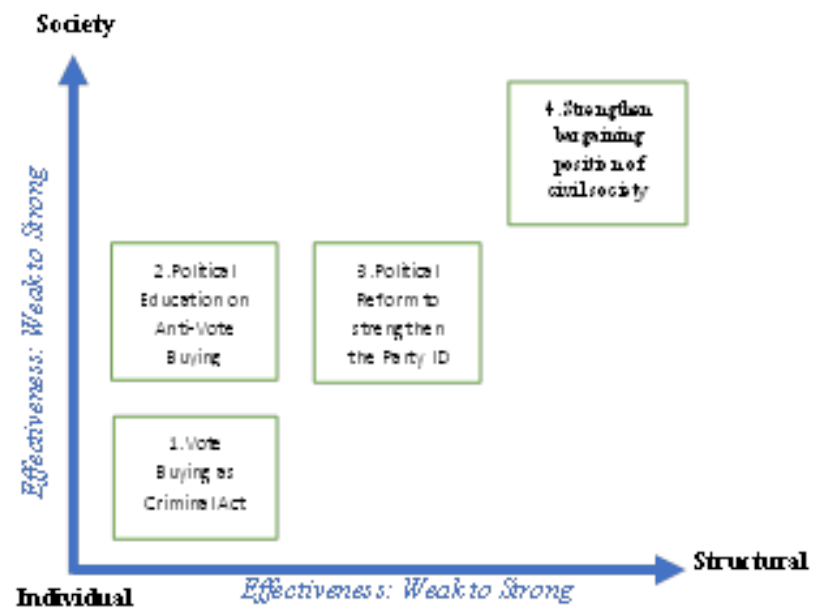

Fig. 1. Solution map to stop vote buying.

From the figure above, two quadrants emerge, namely structural solutions and solutions to society. The four solutions intersect in these two quadrants. The first solution, vote buying as a criminal act will certainly deter individuals from votes buying practices, but in daily life, there are rare cases that can be proven. Then, the second solution is political education to refuse vote buying. Unfortunately, this solution is often just routine on election moment and never really change or stop the vote buying. The third solution is the institutional reform of political parties to make them have the ideological closeness to the masses. This solution is classified as intermediate because providing improvements to the internal party structure and political awareness for citizens/society. Finally, the fourth solution, strengthen the bargaining position of civil society is the best solution. With a strong civil society, the power relations between politicians and citizens will be more equal.

\section{Conclusion}

It can be seen, from the description above, that vote-buying has damaged accountability in the political representation system [62]. If this phenomenon lasts for the long time, people will be ignorant even though the elected candidate is of poor quality [63], and in the more extreme context, elections can fall into "a brutally self-interested sport in which callous people use whatever" [24]. Of course, this kind of condition could not be tolerated, so a handling solution should be needed to anticipate the worsening of vote-buying practice.

From previous researches, there are several solutions which have been proposed, including making vote-buying as crime act; anti-socializing anti-vote buying campaign; reforming party institution to actively carry out ideological-based works; and strengthening the bargaining position of civil society in electoral politics. Each of the solutions certainly has inherent weaknesses, but it still has the opportunity to run in the hope that it can slightly reduce or restrain the vote-buying to be even greater. As a political scientist, producing an 
optimistic perspective needs to be done continuously, rather than always reproducing a pessimistic point of view in seeing various issues surrounding elections.

\section{References}

[1] J. S. Migdal, Strong societies and weak states: state-society relations and state capabilities in the Third World. Princeton University Press, 1988.

[2] J. T. Sidel, Capital, coercion, and crime: Bossism in the Philippines. Stanford University Press, 1999.

[3] C. Peter et al., Shadow state: The politics of state capture. NYU Press, 2018.

[4] S. Hidayat, "Shadow state...? Bisnis dan politik di provinsi Banten," Polit. Lokal di Indones., 2008.

[5] A. E. Ruud and M. M. Islam, "Political dynasty formation in Bangladesh," South Asia J. South Asian Stud., vol. 39, no. 2, pp. 401-414, 2016.

[6] S. Thananithichot and W. Satidporn, "Political dynasties in Thailand: the recent picture after the 2011 general election," Asian Stud. Rev., vol. 40, no. 3, pp. 340-359, 2016.

[7] J. A. Winters, Oligarchy. Cambridge University Press, 2011.

[8] R. Robison and V. R. Hadiz, Reorganising power in Indonesia: The politics of oligarchy in an age of markets, vol. 3. Psychology Press, 2004.

[9] F. Zakaria, "The rise of illiberal democracy," Foreign Aff., vol. 76, p. 22, 1997.

[10] D. Bourchier, Illiberal democracy in Indonesia: The ideology of the family state. Routledge, 2014.

[11] R. H. Mitchell, Political bribery in Japan. University of Hawaii Press, 1996.

[12] M. Najib, "Keterlibatan Penyelenggara Pemilu dalam Vote Trading," Yogyakarta: Polgov, 2015.

[13] A. McGrath, The Forging of Votes. Towerhouse Publications, 1994.

[14] F. Lehoucq, "Electoral fraud: Causes, types, and consequences," Annu. Rev. Polit. Sci., vol. 6, no. 1 , pp. 233-256, 2003.

[15] A. G. Karim, "Mengelola Polarisasi Politik dalam Sirkulasi Kekuasaan di Indonesia: Catatan bagi Agenda Riset," Polit. J. Ilmu Polit., vol. 10, no. 2, pp. 215-228, 2019.

[16] J. Hickman, "Explaining post-election violence in Kenya and Zimbabwe," J. Third World Stud., vol. 28, no. 1, pp. 29-46, 2011.

[17] Rubaidi, “'Jawa Timur: Klientelisme Baru dan Pudarnya Politik Aliran. Dalam Politik Uang di Indonesia: Patronase dan Klientelisme pada Pemilu Legislatif 2014,'” E. Aspinall M. Sukmajati, 2015.

[18] M. N. Franklin, Voter turnout and the dynamics of electoral competition in established democracies since 1945. Cambridge University Press, 2004.

[19] P. C. Vicente, "Is vote buying effective? Evidence from a field experiment in West Africa," Econ. J., vol. 124, no. 574, pp. F356-F387, 2014.

[20] P. C. Vicente and L. Wantchekon, "Clientelism and vote buying: lessons from field experiments in African elections," Oxford Rev. Econ. Policy, vol. 25, no. 2, pp. 292-305, 2009.

[21] V. Brusco, M. Nazareno, and S. C. Stokes, "Vote buying in Argentina," Lat. Am. Res. Rev., pp. 66-88, 2004.

[22] E. Gonzalez-Ocantos, C. K. De Jonge, C. Meléndez, J. Osorio, and D. W. Nickerson, "Vote buying and social desirability bias: Experimental evidence from Nicaragua," Am. J. Pol. Sci., vol. 56, no. 1, pp. 202-217, 2012.

[23] E. Gonzalez Ocantos, C. K. De Jonge, and D. W. Nickerson, "The conditionality of vote-buying norms: Experimental evidence from Latin America," Am. J. Pol. Sci., vol. 58, no. 1, pp. 197$211,2014$.

[24] C. Still and S. Dusi, "Vote buying and 'Money-Politics' in village elections in South India," Commonw. Comp. Polit., vol. 58, no. 1, pp. 100-119, 2020.

[25] P. Rollier, "The lion's share: elections and democracy in Pakistan," Commonw. Comp. Polit., vol. 58, no. 1, pp. 120-138, 2020. 
[26] W. A. Callahan and D. McCargo, "Vote-buying in Thailand's northeast: the July 1995 general election," Asian Surv., vol. 36, no. 4, pp. 376-392, 1996.

[27] F. V Aguilar and M. G. J. P. Alis, "Brokers courting voters: the alliance system in a rural Philippine village," Philipp. Polit. Sci. J., vol. 39, no. 2, pp. 73-96, 2018.

[28] G. W. Cox and M. F. Thies, "How Much Does Money Matter? 'Buying' Votes in Japan, 19671990," Comp. Polit. Stud., vol. 33, no. 1, pp. 37-57, 2000.

[29] M. S. Kochin and L. A. Kochin, "When is buying votes wrong?," Public Choice, vol. 97, no. 4, pp. 645-662, 1998.

[30] K. Kasara and I. Mares, "Unfinished business: The democratization of electoral practices in Britain and Germany," Comp. Polit. Stud., vol. 50, no. 5, pp. 636-664, 2017.

[31] F. Fitriyah, "CARA KERJA POLITIK UANG (Studi Kasus Pilkada dan Pilkades di Kabupaten Pati)," Polit. J. Ilmu Polit., vol. 6, no. 2, pp. 101-111.

[32] G. T. I. Tawakkal, W. Suhardono, A. D. Garner, and T. Seitz, "Consistency and Vote Buying: Income, Education, and Attitudes about Vote Buying in Indonesia," J. East Asian Stud., vol. 17, no. 3, pp. 313-329, 2017.

[33] E. Aspinall, "When brokers betray: Clientelism, social networks, and electoral politics in Indonesia," Crit. Asian Stud., vol. 46, no. 4, pp. 545-570, 2014.

[34] G. T. I. Tawakkal, R. Damayanti, T. Subekti, F. Alfian, and A. D. Garner, "Social networks and brokerage behavior in Indonesian elections: Evidence from Central Java," Asian Aff. An Am. Rev., pp. 1-18, 2020.

[35] T. Zhao, "Vote buying and land takings in China's village elections," J. Contemp. China, vol. 27 , no. 110 , pp. 277-294, 2018.

[36] P. S. Jensen and M. K. Justesen, "Poverty and vote buying: Survey-based evidence from Africa," Elect. Stud., vol. 33, pp. 220-232, 2014.

[37] H. Kitschelt and S. I. Wilkinson, Patrons, clients and policies: Patterns of democratic accountability and political competition. Cambridge University Press, 2007.

[38] E. Kramon, "Where is vote buying effective? Evidence from a list experiment in Kenya," Elect. Stud., vol. 44, pp. 397-408, 2016.

[39] F. Finan and L. Schechter, "Vote-buying and reciprocity," Econometrica, vol. 80, no. 2, pp. 863-881, 2012.

[40] T. A. Canare, R. U. Mendoza, and M. A. Lopez, "An empirical analysis of vote buying among the poor: Evidence from elections in the Philippines," South East Asia Res., vol. 26, no. 1, pp. 58-84, 2018.

[41] G. T. I. Tawakkal and A. D. Garner, "Unopposed but not Uncontested: Brokers and" Vote Buying" in the 2017 Pati District Election," Contemp. Southeast Asia, pp. 491-510, 2017.

[42] W. Aspinall, E., \& Berenschot, Democracy for Sale: Pemilihan Umum, Klientelisme, dan Negara di Indonesia. Yayasan Pustaka Obor Indonesia, 2019.

[43] E. Aspinall and A. Hicken, "Guns for hire and enduring machines: clientelism beyond parties in Indonesia and the Philippines," Democratization, vol. 27, no. 1, pp. 137-156, 2020.

[44] G. T. I. Tawakkal, "Gapit: Jaringan Mobilisasi Suara di Pilkades," Polit. Indones. Indones. Polit. Sci. Rev., vol. 2, no. 1, pp. 30-45, 2017.

[45] S. Kumar, "Uttar Pradesh local elections 2015: money, muscle and manipulation in a village," Commonw. Comp. Polit., vol. 58, no. 1, pp. 43-62, 2020.

[46] M. Bratton, "Vote buying and violence in Nigerian election campaigns," Elect. Stud., vol. 27, no. 4, pp. 621-632, 2008.

[47] S. Khemani, Buying Votes vs Supplying Public Services: Political Incentives to Under-Invest in Pro-Poor Policies. The World Bank, 2013.

[48] I. T. Sihidi, L. N. Khanifah, and A. A. Romadhan, "Relasi Politik Uang dan Party-ID di Indonesia," Cosmogov, vol. 5, no. 2, pp. 204-220, 2019.

[49] B. Muhtadi, "Politik uang dan dinamika elektoral di Indonesia: Sebuah kajian awal interaksi antara 'Party-ID' dan Patron-Klien,” J. Penelit. Polit., vol. 10, no. 1, p. 17, 2013.

[50] I. Sriyanto, "Praktik Politik Uang dalam Perspektif Hukum Pidana," Lex Jurnalica, vol. 1, no. 1, p. 17924, 2003. 
[51] H. Satria, "Politik Hukum Tindak Pidana Politik Uang dalam Pemilihan Umum di Indonesia," Integritas J. Antikorupsi, vol. 5, no. 1, pp. 1-14, 2019.

[52] A. Parlindungan, "Analisis Penegakan Hukum terhadap Tindak Pidana Politik Uang dalam Pemilihan Kepala Daerah ditinjau dari Undang-Undang Nomor 10 Tahun 2016,” J. Educ. Hum. Soc. Sci., vol. 2, no. 2, pp. 335-351, 2019.

[53] J. J. P. Wouters, "What Makes a Good Politician? Democratic Representation,'VoteBuying'and the MLA Handbook in Nagaland, Northeast India," South Asia J. South Asian Stud., vol. 41, no. 4, pp. 806-826, 2018.

[54] M. E. T. Pahlevi and A. A. Amrurobbi, "Pendidikan Politik dalam Pencegahan Politik Uang Melalui Gerakan Masyarakat Desa," Integritas J. Antikorupsi, vol. 6, no. 1, pp. 141-152, 2020.

[55] K. E. R. Marsudi and S. Sunarso, "Revitalisasi Pendidikan Politik Melalui Pembentukan Kampung Anti Money Politic,” JPPUMA J. Ilmu Pemerintah. dan Sos. Polit. Univ. Medan Area, vol. 7, no. 2, pp. 111-121, 2019.

[56] A. Savirani, O. Tornquist, and K. Stoke, "Demokrasi di Indonesia: Antara Patronase dan Populisme," Ringkasan Eksek. Proj. Power, Welfare, Democr. Univ. Gadjah Mada Oslo Univ., 2014.

[57] M. F. Aminuddin and M. F. S. Ramadlan, "Match-All party: pragmatisme politik dan munculnya spesies baru partai politik di Indonesia pasca Pemilu 2009," J. Polit., vol. 1, no. 1, pp. 39-74, 2015.

[58] M. Nurhasim, "Kegagalan Modernisasi Partai Politik di Era Reformasi," J. Penelit. Polit., vol. 10, no. 1 , p. 12, 2013.

[59] W. A. Callahan, "Social capital and corruption: Vote buying and the politics of reform in Thailand," Perspect. Polit., pp. 495-508, 2005.

[60] J. Ferguson, The anti-politics machine: 'development', depoliticization and bureaucratic power in Lesotho. CUP Archive, 1990.

[61] W. A. Callahan, "The discourse of vote buying and political reform in Thailand," Pac. Aff., vol. 78, no. 1, pp. 95-113, 2005.

[62] E. Kramon, "Vote buying and accountability in democratic Africa." UCLA, 2013.

[63] J. Leight, D. Foarta, R. Pande, and L. Ralston, "Value for money? Vote-buying and politician accountability," J. Public Econ., vol. 190, p. 104227, 2020. 